\title{
LESSONS OF COOPERATION BETWEEN GOVERNMENT AND NON-GOVERNMENTAL ORGANIZATIONS IN EMERGENCY MANAGEMENT IN THE CZECH REPUBLIC
}

\author{
J. DOSTÁL \\ Department of Public Economics, Faculty of Economics and Administration, Masaryk University, \\ Czech Republic.
}

\begin{abstract}
The purpose of this research is to identify the strengths and weaknesses of the current forms of cooperation between government and non-governmental organizations (NGOs) in emergency management in the Czech Republic, while presenting a detailed overview of the key criteria of the effective Czech model, which could be potentially used by other organizations or countries. Previous research has focused on cooperation between government and NGOs in flood risk management, but emergency management concerns more than floods. The scope has been expanded to include volunteer firefighters and rescue workers, the other NGO players in emergencies in the Czech Republic. The research presents an overview of the cooperation between the Czech government and NGOs in various forms of emergency management. Using document review and a series of interviews with emergency management experts, several aspects of cooperation were considered: formalization, timing, level, and type. The research findings demonstrate that some emergency management activities can be very effectively performed by NGOs and their volunteers. In the Czech Republic, integration into the national Integrated Rescue System guarantees a minimum standard of performance. Since volunteers work for free and their work has much lower expenses, they perform their activities in a more cost-effective way than the state. However, this is not valid for the whole emergency management system, but only for such activities that can be assigned to volunteers when there are enough willing volunteers and the NGOs and their volunteers are formally integrated into the rescue system. The Czech experience could be interesting for other countries, particularly post-communist countries, because all emergency systems work with information, and the human factor plays a role everywhere. Thus, it is concluded that some basic aspects of cooperation in Czech emergency management, focused on sharing information and strengthening mutual trust and awareness, could be considered as universal.
\end{abstract}

Keywords: cooperation, Czech Republic, emergency management, government, non-governmental organizations.

\section{INTRODUCTION}

While NGO cooperation in emergency management is still an emerging field of scholarship [1], many recent studies have examined the activities of NGOs and volunteers in emergencies. These studies are usually focused on a particular, often territorial, issue. Some studies have addressed aspects of NGO and volunteer activities in emergencies in the United States. Wetmore [2] studied New Orleans, Louisiana, USA, where NGOs took part in the system of flood mitigation. At least three overlapping systems sought to address potential problems at different phases. This has some benefits, for example, when one system fails, another system designed by another group of people might be able to handle the situation. However, there are also significant disadvantages, because a loose system of distributed responsibility can cause a great deal of confusion and miscommunication.

Wetmore [2] wrote that when these systems fail spectacularly, the failure is rarely the responsibility of just one person; concluding that understanding and respecting the other components of a system can facilitate the communication necessary to mitigate the weaknesses inherent in systems of distributed responsibility. This is in agreement with a 2010 
study from the Czech Republic of Rektořík et al. [3] that concluded that the most important element of cooperation in flood risk management in the Czech Republic is mutual communication and information sharing among all participating parties (NGOs, public administration, Fire Rescue Service (FRS), etc.). Another conclusion of the Czech study was that the government's fear and lack of trust towards NGOs limited the cooperation between NGOs and government. In another US study, Stys [4] researched a tropical storm and subsequent flood in Houston, TX. Insufficient coordination of response operations resulted in various organizations duplicating each other's activities. It took 6 months to establish a framework of cooperation, again due to insufficient cooperation and information sharing.

In a study of the 11th September terrorist attack on the World Trade Centre, Carson [1] mentioned ongoing public criticism about the perceived lack of efficiency among the various relief agencies and emergency funds in assisting the victims of these attacks. Families of the victims have complained that it has been difficult for them to receive funds because of the lack of coordination among funding sources and the limited information from the volunteers who are assisting them. The same problems are apparent: lack of coordination and lack of information sharing.

Eller and Gerber [5] found one important failure across the USA: the lack of well-developed working relationships between government officials and voluntary non-profit organizations. They also found that many volunteer organizations engage in disaster recovery and relief service provision when a disaster strikes a given community on an ad hoc basis, not developing routine relationships with key government agencies. Eller and Gerber [5] suggested that a regular means of communication between partners and sectors improves trust levels.

Brudney and Gazley [6] found a positive association between a county emergency manager's perception of preparedness and the frequency with which voluntary organizations participated in emergency planning. Many authors, for example, Eller and Gerber [5], McGuire [7], and Gazley [8] agree that the following factors improve perceptions of collaborative success in cross-sectoral partnerships: goal agreement, stability among partners, training, and prior cross-sectoral experience. According to the information from these studies and Czech practices, these factors are also important in Czech emergency management.

Bennett et al. [9] concluded that coordination with other aid actors can help with the division of labour, which has proven true in the Czech Republic. It is one of the main reasons for creating a coordination working group called the panel of NGOs. Bennett also concluded that coordination can help establish guidelines for best practices and norms for proper conduct and can act as a reference point and analytical resource on sector-wide issues. Such coordination takes place in the Czech Republic in the form of information sharing by several working groups and in the creation of information material about various types of NGO emergency activities.

Diagne [10] studied Saint Louis, Senegal, a region that is at high risk from flooding, further exacerbated by climate change, both from sea-level rise and increased water flows in the river. Diagne claims that if no action is taken, the long-term viability of the city is in doubt. Although efforts to alleviate the effect of flooding were undertaken under the direction of the government, Diagne also mentions the important role of some NGOs in these efforts in the areas of research and action.

Volunteer firefighters are a specific area of emergency response. In Australia, McLennan and Birch [11] investigated volunteer firefighters. They concluded that the volunteer firefighters save the Australian government 9 billion USD annually. Volunteer firefighters have been investigated in terms of motivation by Thompson and Bono [12], and the effects of volunteer 
firefighter activities were examined by Yarnal and Dowler [13]. The value of emergency volunteering was studied by the International Federation of Red Cross and Red Crescent Societies. According to this study, the value of volunteering through the Red Cross and Red Crescent Societies is six billion USD annually [14]. Studies from the Czech Republic are less frequent.

There are several reasons to research volunteering specifically in emergencies. Emergencies are an object of public policy and specifically of security policy. Financial support for emergency-directed NGOs often comes from budgets designated for emergency or disaster management. In the Czech Republic, parts of public budgets are designated for emergency management, such as regional budgets [15] and the budget of the FRS of the Czech Republic $[15,16]$. The basic goal of emergency management is to save lives, health, and property. NGOs help to achieve this goal through various activities including humanitarian aid, rescue operations of volunteer firefighters and rescue workers, first aid and psychosocial support, and cleaning operations.

Kumar [17] focused on one aspect of cooperation: NGO humanitarian aid coordination. Kumar studied the 2002 flood in the Czech Republic and concluded that Czech NGOs, in general, needed to become more sensitive to the process of developing common approaches in advance, sharing information, developing joint plans, and taking coordinated preparedness action in order to improve their relief efforts. Looking to the current situation in the Czech Republic, it is clear that the NGOs have become involved in crisis planning that they are trying to coordinate their efforts in this area, and that they are aware of the need for sharing information $[3,16]$.

Dostál and Balarinová [18] stated that failure to provide volunteer aid in emergencies would probably have fatal impacts on the Integrated Rescue System (IRS) of the Czech Republic, especially on the provision of water rescue services, mountain rescue services, and fire protection, and the decrease in human resources to cope with the consequences of flooding would also be considerable. Their study estimates the economic value of selected types of volunteering in emergencies as running to hundreds of thousands of euro for individual types of volunteering. The gross estimates for the total volunteer firefighting in the Czech Republic amount to millions of euro annually. The purpose of this paper is to identify the strengths and weaknesses of the current forms of cooperation between government and non-governmental organizations (NGOs) in emergency management in the Czech Republic, while presenting a detailed overview of the key criteria of the effective Czech model [16], which could be potentially used by other organizations or countries.

\section{IMPORTANCE OF NGO PARTICIPATION IN EMERGENCY MANAGEMENT}

The benefit of NGO participation in emergency management is that NGOs add additional resources (financial, material, and human) to the national emergency system, the IRS. They use their goodwill to collect financial support even from citizens who do not trust the government enough to give money voluntarily to government organizations.

This was the case in Bangladesh, where after a flood in 1974 the government totally failed to provide financial aid to the affected people. The public concluded that the government was ineffective and maybe even corrupt. The result was that most humanitarian aid in Bangladesh started to flow through NGOs and not through the government [19]. A similar principle was found in the Czech Republic. In 1997, the Czech Republic was affected by the first devastating flood in modern history. In this flood, NGOs were much more flexible and effective than the government in relief operations, and the public rewarded them with generous support. 
This excellent performance by the humanitarian NGOs brought about a dramatic change in the Czech attitudes towards the whole sector. When the next big flood occurred in 2002, the public gave almost exclusively through NGOs and not through the government's public collections [20]. These Czech experiences reveal another benefit of NGO participation in emergency management: NGOs are usually less bureaucratic and more flexible in providing humanitarian aid, which make them faster than the official government. Another significant benefit of NGO participation in emergency management is that many people serve as emergency volunteers through NGOs. At the occurrence of the 1997 flood, the Czech Army, which at the time had about 207,000 soldiers, participated significantly in flood response and recovery. According to some, the Czech military was the only state force that did not fail in flood response and recovery operations [20]. In 1999, the Czech Republic joined the North Atlantic Treaty Organization, which resulted in the professionalization of the Czech military in 2005. The number of soldiers diminished significantly, to about 26,000, which limits the ability of the Czech military to assist in big emergencies such as floods [21].

The Czech government do not have any extra reserves for big emergencies. Even smaller emergencies, such as fires or accidents in the mountains or in the water, cannot be handled without volunteers. There are about 75,000 active volunteer firefighters in the Czech Republic. An additional 300,000 people are members of volunteer firefighter associations. There are about 9,000 professional firefighters and about 6,400 of them work in the field implying that there are almost 12 active volunteer firefighters for each professional in the field [22]. Table 1 shows the number of professional firefighters and volunteer firefighters who worked in flood management in 1997, 2002, and 2013.

Active volunteer firefighters are members of municipal volunteer firefighter units and act as volunteers working for the municipality. Volunteer firefighter associations, which are NGOs, help to find and educate new volunteer firefighters, prevent fires, inform the public during floods, assist with evacuations, provide shelter for evacuated citizens, amongst other duties [26].

Mountain rescue service is a significant part of volunteer rescue work. About 400 volunteer rescuers and 110 professionals work in the Czech mountains: approximately 3.6 volunteers for each professional [27]. The core of mountain rescues service is to help in accidents on mountains, find lost people, transport injured people to the hospital, provide first aid, and mount rescue operations. This could also happen when floods occur, because floods affect cities in mountain areas. Their contribution in flood management is that they can offer specialist resources to the system, including highly skilled people, who are used to extraordinary environment and people who know the area where they are working.

Water rescue services are also part of Czech volunteer rescue work. There are no professional water rescue groups in the Czech Republic. The Water Rescue Service of Czech Red Cross is a major player, with about 1450 volunteers, and there are also several minor ones

Table 1: Firefighter flood management participation.

\begin{tabular}{lccr}
\hline Year of flood & 1997 & 2002 & 2013 \\
\hline Professional firefighters participating in flood operations & 3,748 & 5,135 & 4,531 \\
Total number of professional firefighters working in the field & N/A & 6,050 & 6,249 \\
Volunteer firefighters participating in flood operations & 13,213 & 19,044 & 14,904 \\
\hline
\end{tabular}

Source: Prudil [23], Annual Reports of the Fire Rescue Service [24,25]. 
[22]. During floods, they help with evacuations and provide humanitarian aid. Water is a natural environment for them and they have various experiences in smaller water (non-flood) emergencies.

Another reason for researching the situation of NGOs in Central and Eastern Europe is that, as Palubinskas observed [28], Communism in Central and Eastern Europe resulted in the virtual elimination of NGOs so these countries only started working again with NGOs in the late 1980s. Although some current NGOs were active during communism, they were in fact not non-governmental at that time but have become so in the post-communist era. Thus, the former communist Central and Eastern European countries entered the modern era of NGOs from the same starting position. Many of them have trouble with floods and other emergencies. The participation of the NGOs in the Czech system of emergency management and the cooperation of Czech NGOs could thus serve as an example for these countries.

\section{CZECH-INTEGRATED RESCUE SYSTEM}

The Czech emergency management system is called the IRS. It facilitates cooperation and coordination between public administration and rescue forces in emergency management, including rescue operations. There has historically been an interest in cooperating for fast and effective emergency response. Cooperation in emergency management thus existed even before the IRS, as has the need to coordinate emergency activities. The Czech law on the IRS [29] says that the IRS coordinates actions and procedures in emergency preparedness, response, and recovery. The IRS is used when preparing for emergencies with more than one of the components of IRS. The law on the IRS differentiates basic and other components. This law also establishes authorizations (permissions), responsibilities, and fields of action in rescue operations and civil protection.

\subsection{Components of IRS}

The basic components of the IRS are the FRS of the Czech Republic, FRS units included in the district area covered by FRS units (including volunteer firefighters), Medical Rescue Service, and the Police of the Czech Republic.

The other components are: determined units and equipment of army forces; other armed security forces; other rescue forces; public health authorities; accident, emergency, expertise, and other services; civil protection facilities; and non-profit organizations and citizen associations that can be used for rescue and clean-up operations (they usually use volunteers for these activities) [30].

All the basic components have three characteristics in common:

- They are able to react quickly and continually.

- Their response is available across whole Czech Republic.

- They operate emergency phone lines.

The other IRS components provide requested scheduled help with rescue and recovery operations, based on contracts. This is also true for several NGOs.

\subsection{Aims and principles of the IRS}

The IRS is aimed at coordinating preparedness and recovery operations when emergencies (e.g. natural disasters, terrorist attacks, pandemics, accidents) occur. The purpose of the 
system is to fulfil the human right to help when life or health are threatened which is guaranteed in the Czech constitution. The IRS was created due to the need to coordinate the daily activities of rescuers, especially during complicated accidents and natural disasters (especially floods) when it is important to organize the activities of all actors who can and want to contribute to saving the lives and health of people and animals and to protecting the environment [22].

The main principle of IRS is that anyone who can help should be included, but at the same time the particular actors should not encumber each other. This is very difficult to coordinate during an emergency; thus, this process requires clear rules set out in advance.

As was said above, the IRS is not an institution, an office, or a legal entity. It is a system of cooperation and coordination using model processes, contracts, and rules, and it is also part of the national system for internal security [22]. There is one very significant exception: the operational and information centres. These centres are very important parts of the IRS and work as dispatchers. They have the most modern technologies and equipment for receiving and evaluating emergency calls through the European Emergency Number 112. These centres have employees and technical equipment in each of $14 \mathrm{Czech}$ regions. They are part of FRS of a particular region, with the FRS supplying them with material and labour force.

\section{METHODOLOGY}

The first half of the paper presented an overview of why NGOs are important in the Czech emergency management system and the legal framework and principles of IRS. The second half explores cooperation between NGOs and the government.

Primary data were acquired from semi-structured interviews with the key representatives of the most prominent humanitarian NGOs. The interviews took part in the first half of 2011. Kumar [17] presented a list of the most prominent humanitarian NGOs in the Czech Republic (ADRA, Czech Red Cross, People in Need, Diaconia, and Caritas). Starting with the ADRA, which is well known for activities in emergency management and which is one of the biggest NGOs providing volunteer help to other subjects. Snowball sampling was used to choose other NGOs by moving on to others along the chain. The data sample was closed at $n=6$, as the five NGOs identified by Kumar plus Hand for Help. Because Kumar [17] found roughly the same NGOs to be the most prominent ones, one can conclude that there are still about five or six major NGOs in this area. The reason for using snowball sampling was the presumption that in the Czech Republic there are a relatively small number of this type of NGO and they are doing almost all activities in this area.

The list of the chosen NGOs is shown in Table 2. The sixth NGO, Hand for Help, went bankrupt and is no longer active. Although many other NGOs participate in Czech flood risk management, the NGOs selected appear to be the most prominent participants.

After choosing the NGOs for managed interviews, it was necessary to identify the relevant positions to be interviewed. In order to ensure the findings' relevance, the highest relevant position possible was interviewed. Managed interviews were thus held with two NGO heads, one economic director, and four individuals responsible for humanitarian aid in the Czech Republic. The positions of the NGO representatives are shown in Table 2.

All the NGOs were extremely willing to participate in this research. These interviews were a central part of the research because they represent the views of the main players in this field. The research was part of a larger research project for the Ministry of the Finance in June 2011. These questions were given to the NGO representatives. 
Table 2: NGOs participating in flood risk management.

\begin{tabular}{ll}
\hline NGO & Position of the NGO representative \\
\hline ADRA & Coordinator of humanitarian help in the Czech Republic; \\
& Economic director \\
Czech Red Cross & President \\
People in Need & Head of flood programmes \\
Diaconia & Person responsible for humanitarian aid \\
Caritas & Head of humanitarian department - Archdiocesan Caritas \\
& Olomouc \\
\hline
\end{tabular}

Source: Author.

1. Did you participate in emergency management in the past? What was the scope of your participation?

2. In what ways do you cooperate with municipalities in emergency management? What are the limitations and risks of that cooperation?

3. Would you like to be involved in crisis planning? Do you have anything to offer?

4. Would you like to participate in taskforce sessions? Do you have anything to offer? What value would be added by your participation?

5. In your opinion, is the cooperation among NGOs in area of emergency management sufficient? How could this cooperation be supported?

6. What are the financial resources for your NGO when you participate in emergency management?

7. Do you know about any other relevant NGO that should be a part of this research?

The following features were evaluated from the results of the interviews:

1. Participation of the NGOs in emergency management.

2. Limits of the participation. Methods of cooperation between municipalities and NGOs.

3. Limits of the cooperation. Involvement in crisis planning, present and potential.

4. Involvement into the taskforce sessions, present and potential.

5. The sufficiency of cooperation in the opinions of NGOs.

6. Possible tools for improving cooperation.

7. The financial resources of NGOs in emergency management.

The results of the interviews were reported to the Czech Ministry of Finance [3], so wherever there is information from these interviews in the text, there is a reference to the report.

After the initial research, the author became a member of a working group under the Czech Ministry of the Interior, the Emergency and Crisis Volunteer Working Group. Results of the study for the Ministry of Finance were partly verified and additional information was gathered while participating in this working group. The research was further extended by including major players from two other important groups in Czech emergency management: volunteer firefighters and volunteer rescuers. Further data about their cooperation were gained by the document review, particularly from their websites and specialized publications [22]. Information about these NGOs is presented in Table 3. The interview responses were 
Table 3: Other major emergency management NGOs in the Czech Republic.

\begin{tabular}{lll}
$\begin{array}{l}\text { Type of volunteering } \\
\text { in emergencies }\end{array}$ & Subtype & NGOs \\
\hline Volunteer rescuers & Water rescuers & $\begin{array}{l}\text { Major player: Water Rescue Service of } \\
\text { Czech Red Cross; several minor ones } \\
\text { Two NGOs: Mountain Rescue Service } \\
\text { (the name is the same, but the legal form is } \\
\text { different) }\end{array}$ \\
Volunteer firefighters & $\begin{array}{l}\text { Major player: Association of Firefighters of Bohemia, Moravia and } \\
\text { Silesia; several minor ones }\end{array}$
\end{tabular}

Source: Author.

sorted into several categories, such as: involvement in crisis plans (yes or no), type of involvement (which kind of help NGOs are providing according to the plan), which type of local governments (regional, municipal), where (particular regions or municipalities), any problems with this type of cooperation (no problems or none mentioned), and the compensation from the government. These were referred to in the third question. The other questions were analysed analogically. The seven above-mentioned features were chosen for analysis in the present paper.

Additional interviews were held in 2013 and 2014 regarding the number of volunteer hours of the most prominent NGOs in the 2013 flood, as a part of a bigger research project concerning the methods of evaluating the economic value of volunteering. Part of the subsequent research about the economic value of NGO volunteering during the Czech flood in 2013 was used as an example of the results of cooperation between the government and the NGOs. Without this cooperation, it would not be possible for NGOs to send their volunteers to help with recovery, and such valuable volunteer work would not take place.

Again, the five prominent NGOs were interviewed. Before the 2013 flood, People in Need had decided that they would focus on financial support and not provide the volunteer services, so only four NGOs remain: ADRA, Diaconia, the Czech Red Cross, and Caritas Czech Republic. The positions of the NGOs representatives were the same with one exception: the Red Cross were represented by the deputy chief of the Central Crisis team.

The volunteer hours were evaluated using the approach recommended by International Labour Organisation [31], and Salamon, Sokolowski, and Haddock [32]: each type of volunteer work is evaluated using a specific replacement wage from the Information System on Average Earnings operated by the Ministry of Labour and Social Affairs of the Czech Republic [33]. Tables 4 and 5 show the economic value of NGOs volunteering in the Czech floods in 2013.

\section{RESULTS}

These results presented here relate to cooperation between government and NGOs in emergencies. They are analysed in order to demonstrate the exact nature of the NGOs cooperation with the state in emergency management and the specifics of this cooperation. The results came from interviews and from document review. NGOs participating in Czech emergency management can be divided into two groups: NGOs focused primarily on floods, and volunteer firefighters and rescue NGOs. Among the NGOs focused primarily on floods are five 
large NGOs in the Czech Republic, most of which are connected with international networks: ADRA, Czech Red Cross, People in Need, Diaconia, and Caritas Czech Republic. There are no overall data about their participation in emergency management. There are some specific data about NGO fundraising from past floods, based on which it is clear that NGOs receive quite generous support from the public, according to the current economic director of ADRA, Valešová [3]. Thousands of volunteers through these NGOs help with post-flood recovery. These volunteers work primarily in activities where no special skills or education are necessary, such as cleaning up debris [22]. Volunteers are also increasingly active in emergency psychosocial support. ADRA, with their community intervention team, is one of the major NGOs in this area [22].

The emergency non-profit sector in the Czech Republic is based on five large NGOs providing financial and humanitarian aid, plus mostly unqualified volunteering - these are primarily involved after a flood in the recovery operations, and on volunteer emergency services. These emergency NGOs and volunteers are part of the IRS, which is the state system for emergency management. There are two types of emergency volunteering: those focused on the humanitarian aid and the more semi-professional services that deal with floods as part of their wider role in emergency management and general rescue.

Cooperation between the government and NGOs in emergency management in the Czech Republic is a complicated topic. For this reason, the cooperation was divided into sections: type of cooperation; formalization of cooperation; timing of cooperation; and level of cooperation.

\subsection{Types of cooperation}

There are four major types of cooperation between government and NGOs:

\subsubsection{Sharing information}

The official government emergency coordination platform is called a 'task force' and has representatives from the government and rescue services, as well as some NGO. Czech Red Cross was already present at the session, as was mentioned by the president of the Czech Red Cross, Jukl [3]. The central task force is a working group of the Czech government, the regional task force is a working group of the regional authority, and the municipal task force is a working group of the municipal authority. All these task forces serve the particular authority to improve information sharing. Some NGOs have participated in these task forces.

Another emergency management working group is the Emergency and Crisis Volunteer Group. This informal working group, not founded by law or contracts, is under the Ministry of the Interior of the Czech Republic. The group was established during the European Year of Volunteering in 2011. It includes representatives from the Ministry of the Interior, ADRA, Czech Red Cross, Diaconia, Caritas, the South Bohemian regional authority, ČEZ group, FRS, the Volunteer Fire Service, and Masaryk University.

One of the main goals of the group is to encourage mutual cooperation among NGOs, public administration, and corporate volunteers. Information is also shared at specialized conferences. At these conferences, representatives from various forms of organizations and institutions, including ministries, regional and municipal authorities, FRSs, NGOs, and even foreign countries and the European Commission share information. These conferences have focused on better awareness of each other, on specific trends or problems, on the capabilities and needs of NGOs and local governments, etc. 
5.1.2 Giving approvals or accreditations and signing contracts

A significant financial source of NGO participation in emergencies is financial collections, according to all of the NGO representatives in the interviews [3]. According to the law on public collections, the regional governments of the Czech Republic or the Prague Municipal Office have to give approval for the collection of money in the form of donations from the public.

The Ministry of the Interior also operates an accreditation service for NGOs providing voluntary assistance. The accreditation system is closely connected to the provision of grants to NGOs. The accreditation and grant system is used by various kinds of services, not only for volunteerism as a part of flood risk management. There are two commissions for that purpose: the Accreditation Commission and the Grant Commission. Each commission has nine members and some of the members are the same. The members of the commission are also representatives of other ministries (Foreign Affairs; Labour and Social Affairs; Finance; Culture; Education, Youth and Sport; Environment) [34].

'Panel', the NGO coordination platform, can operate based on contracts. For example, the South Bohemian regional authority signed contracts with NGOs. The most important contribution of the 'Panel' is improving the coordination by means of which each NGO can perform the activity in which it has a comparative advantage. For example, the Czech Red Cross assumes the role of emergency coordinator, ADRA provides seminars for volunteers, the Association of Firefighters of Bohemia cooperates with regional task forces, etc.

Kavan [16] mentions three possible types of contracts between NGOs and the FRS in the IRS of the Czech Republic: contracts about scheduled assistance; contracts for the provision of personal or material assistance, and contracts for cooperation. An NGO could be integrated through the FRS into the regional or municipal crisis plans.

\subsubsection{Financial cooperation}

Czech emergency NGOs receive financial support from Czech ministries. The Ministry of the Interior, for example, provided a financial contribution to ADRA for crisis and emergency plans. The Ministry of Education, Youth and Sport also gave financial assistance of 50,000 CZK (ca. 1960 EUR) to ADRA for activities related to the organization of European Year of Volunteering in the Czech Republic, said ADRA economic director Valešová [3]. Some NGOs receive grants from the General Directorate of the FRS of the Czech Republic, which is part of the Ministry of the Interior. As the president of the Czech Red Cross, Jukl [3] mentioned, the Czech Red Cross receives 30,000 CZK (ca. 1180 EUR), and Diaconia receives between 40,000 (ca. 1570 EUR) and 60,000 CZK (ca. 2350 EUR) per year, added Mutlová, who was responsible for humanitarian aid in Diaconia [3].

When there is a coordination platform based on a contract, such as with the South Bohemian Regional Panel, there could be financial support for NGOs. In South Bohemia, the NGOs receive from 3000 EUR to 20000 EUR per NGO per year, and in turn the NGOs are obliged to perform the contracted activities if there is an emergency. If there is no emergency during the year, the NGOs use this money to finance their usual activities. NGOs also have the opportunity to request increased financial assistance from the regional government if necessary [22]. In the event of an emergency, an evaluation report is produced at the conclusion of the agency's emergency participation. Additional finances come from contracts with FRSs and integration into the regional or municipal crisis plans [3].

A special case of cooperation between Czech NGOs and a central form of government is cooperation with the European Union. NGOs could use cooperation with the European Union 
as a strategy for gaining financial recourse for Czech emergency management work. Some NGOs involved in Czech emergency management have had experience with projects supported by EU Structural Funds, but in most cases these projects are from areas not related to flood risk management activities. For example, ADRA has a project for assisting victims of domestic violence and working with children with behavioural problems, said economic director Valešová [3]. The only projects supported by the structural funds related to emergency management are projects of Czech Red Cross for disaster preparedness.

\subsubsection{Cooperation on the legislative process}

NGOs have to respect the laws. The Czech rescue system is evolving and so is the legal system. There is a trend to involve NGOs in that evolution. The Czech government has a Council for Non-Governmental Non-Profit Organizations. The council has several committees, including the Committee for Regions, whose role is to encourage NGO-regional authority relations, and the Committee for Legislation and Finance, whose role is to regulate the nonprofit sector [35]. Three laws were prominent in relation to NGO participation in flood risk management: the law on public benefits, the law on financial collection, and the civil code. The director of Caritas Czech Republic, a prominent NGO participating in Czech flood risk management, is a current member of this Council, and there are also representatives of other NGOs from different areas [36]. NGOs sometimes have the opportunity to comment on regional crisis plans and use their experiences to influence new versions of these plans.

\subsection{Formalization of cooperation}

In the 21st century Czech Republic, not every type of cooperation is formal. Mutual interactions among interested subjects are conducted at both formal and informal levels. When there is an emergency, NGOs try to contact the Mayors of the affected municipalities to ask about their needs and inform them about their own capacities. During an emergency, the head of the intervention a fire rescue officer, or even the Mayor (this option is possible according to the law, but does not happen in reality, because the fire rescue officers are more skilled and competent) gives orders to all IRS parties at the emergency site, including NGOs [3].

NGOs help with recovery either because they are obliged to by contract (which they previously voluntarily signed) or because they decide to do so, but it both cases it is based on their capacity to help. NGOs coordinate their activities with other NGOs and local authorities. This coordination can be unofficial, with representatives sharing information, or official, based on a contract and with support (including financial support) from the regional or municipal authority. Contracts and financial support are important to ensure continuity because NGOs need financial resources to remain fully prepared for emergencies. The public donates money when emergencies occur, but local authorities can provide financial resources in 'peace time' enabling NGOs to prepare for emergencies more effectively.

Not all cooperation between the government and NGOs is formalized. Cooperation can take formal and informal forms. This is obvious from the interviews [3] and also from the professional conferences and sessions of the working group of the Ministry of Interior of which the author is a member. Cooperation is dependent on the willingness of the actors to establish relations (formal or informal), mutual trust, and the stable resources of the NGO (so they are able to keep their commitments).

Advantages of informal cooperation include greater flexibility and the establishment of more friendly relations (e.g. at conferences or sessions of informal working groups). However, 
there are also disadvantages in the form of limitations of the cooperation emergencies because of the legally determined processes in the IRS. The biggest advantage of formal cooperation is that NGOs have clear roles in the IRS and in many cases know what financial support they will receive from the state. The greatest disadvantage, or rather potential risk, is if NGOs lose their flexibility and independence from the state. Flexibility is important, because citizens affected by flood must have their basic needs met immediately. NGOs have much less complex bureaucracy, so they can give money to the people in need almost immediately, after monitoring the situation. Formal agreements could add a layer of bureaucracy and diminish this advantage. They can fill the gaps where the government is not able to intervene flexibly, as happened in the Czech Republic in 1997. They can also replace government in providing financial aid from the public, when the government is believed to be incompetent, as happened in Bangladesh.

\subsection{Timing of cooperation}

Experience has made it increasingly clear that cooperation solely during emergencies is not enough: cooperation during 'peacetime' is also important. There was consensus among the NGO representatives on this [3]. Contact, mutual trust, and good relations among the actors of emergency management are important. This is important for two reasons: better communication during an emergency because of familiarity and trust [37] and better planning between emergencies to increase resilience. This trend can be seen from the conferences after the floods, when there is a willingness to improve the coordination and activities of NGOs, and also from the 'Panel', where NGOs are trying to divide the roles before another flood occurs. In the Czech Republic, cooperation among NGOs at the national level, where NGO leaders know each other and the right government officials, tends to be better than cooperation at the local level, where the NGO representatives often do not know each other, as mentioned by the ADRA coordinator of humanitarian help in the Czech Republic, Koláček [3].

The familiarity at the national level is probably facilitated at least partly through meetings during emergencies and at specialized conferences, working groups, etc. The moment when an emergency happens is at the core of NGO participation. We can distinguish at least two phases. In the beginning, there are professional or volunteer rescuers. After them, if necessary, come volunteer firefighters, NGO employees, and if necessary also volunteers to clean up the debris, etc. Usually these last volunteers come after the rescue operations are over. There is one more group who may be present at an emergency: the emergency managers of the municipal or regional governments, or even the national government. It is important that all these groups usually share the same objectives, but often have different tools, timing, and motivations [22].

Research regarding Czech floods in 2013 has shown that the economic value of volunteering from the prominent NGOs is significant. This volunteer work could hardly be done without cooperation with the government, because of the need to share information and the various processes in emergency management.

The Table 4 shows the economic value of volunteering in the 2013 Czech floods 2013 from the particular NGOs.

The table clearly shows that the Czech Red Cross had a major share in volunteering during this flood. Table 5 shows the economic value of volunteering during the 2013 flood divided according to the types of volunteer work in 2013 flood.

The table shows an interesting result: most of the volunteer work done during the Czech floods in 2013 was well qualified, such as management of psychosocial support. This means that the NGOs are bringing additional human resources into the national emergency system 
Table 4: Economic value of NGO volunteering: 2013 Czech floods.

\begin{tabular}{lccc}
\hline NGO & $\begin{array}{c}\text { Number of } \\
\text { volunteers }\end{array}$ & $\begin{array}{c}\text { Number of volunteer } \\
\text { hours }\end{array}$ & $\begin{array}{c}\text { Economic value } \\
\text { (EUR) }\end{array}$ \\
\hline ADRA & 254 & 8,228 & 34,334 \\
Czech Red Cross & 1,860 & 124,992 & 733,028 \\
Diaconia & 215 & 6,284 & 20,458 \\
Caritas CZ & 222 & 9,880 & 48,157 \\
Total & 2,551 & 149,384 & 835,977 \\
\hline
\end{tabular}

Source: Author.

Table 5: Economic value of NGOs volunteering: Czech floods 2013.

\begin{tabular}{lcccl}
\hline $\begin{array}{l}\text { Type of } \\
\text { volunteering }\end{array}$ & $\begin{array}{c}\text { Number of } \\
\text { volunteers }\end{array}$ & $\begin{array}{c}\text { Number of } \\
\text { volunteer hours }\end{array}$ & $\begin{array}{c}\text { Economic } \\
\text { value (EUR) }\end{array}$ & NGO \\
\hline Manual work & 465 & 14,728 & 42,809 & $\begin{array}{l}\text { ADRA, Caritas, } \\
\text { Diaconia } \\
\text { Caritas, Diaconia }\end{array}$ \\
$\begin{array}{l}\text { Monitoring of } \\
\text { needs }\end{array}$ & 60 & 1,688 & 10,828 & ADRA, Czech Red \\
$\begin{array}{l}\text { Logistics and } \\
\text { management }\end{array}$ & 722 & 70,292 & 442,618 & $\begin{array}{l}\text { ADoss, Caritas, Diaconia } \\
\text { Psychosocial }\end{array}$ \\
$\begin{array}{l}\text { support } \\
\text { First aid }\end{array}$ & 653 & 31,428 & 139,266 & ADRA, Czech Red cross \\
Total & 651 & 31,248 & 200,455 & Czech Red Cross \\
\hline
\end{tabular}

Source: Author.

(IRS), both unqualified (such as cleaning up the debris) and well qualified. Because of the permanent cooperation with the government, the NGOs can prepare their emergency teams, including volunteers, more effectively. As a result of this, through the NGOs, additional emergency workers are flowing into the emergency management system.

\subsection{Level of cooperation}

As was shown in the interviews [3], in Czech emergency management, NGOs cooperate with government at several levels: the European Union level, Czech Republic (national) level, regional level, and municipal level. Table 6 shows the types and levels of cooperation between government and NGOs, as well as how cooperation between government and NGOs works.

In addition to direct cooperation with government, the IRS works on the national, regional, and municipal levels. Table 5 shows the forms of cooperation between NGOs and the basic components of the IRS (Fire Service, Medical Rescue Service, and Police).

It is very important that the NGOs can cooperate with the basic components of the IRS at all levels of cooperation, as is clear from Table 7, especially national, regional, and municipal. 
Table 6: Cooperation between government and NGOs in the Czech Republic.*

\begin{tabular}{|c|c|c|c|c|c|}
\hline \multirow{3}{*}{$\begin{array}{l}\begin{array}{l}\text { Level of } \\
\text { cooperation }\end{array} \\
\text { Type of } \\
\text { authority } \\
\text { Type of } \\
\text { cooperation }\end{array}$} & \multirow{2}{*}{$\begin{array}{l}\begin{array}{l}\text { European } \\
\text { Union level }\end{array} \\
\begin{array}{l}\text { European } \\
\text { commission }\end{array}\end{array}$} & \multicolumn{2}{|c|}{ Czech Republic level } & \multirow{2}{*}{$\begin{array}{l}\text { Regional } \\
\text { level }\end{array}$} & \multirow{2}{*}{$\begin{array}{l}\text { Municipal } \\
\text { level }\end{array}$} \\
\hline & & $\begin{array}{l}\text { Central } \\
\text { government }\end{array}$ & Ministries & & \\
\hline & \multicolumn{5}{|c|}{ Financial support from government } \\
\hline & \multicolumn{5}{|c|}{ Sharing of information } \\
\hline & Contracts & $\mathrm{x}$ & \multicolumn{3}{|c|}{ Contracts, accreditation, approvals } \\
\hline & $\mathrm{x}$ & $\begin{array}{l}\text { Task force } \\
\text { session }\end{array}$ & $\mathrm{x}$ & \multicolumn{2}{|c|}{ Taskforce session } \\
\hline & $\mathrm{x}$ & Crisis plans & $\mathrm{x}$ & \multicolumn{2}{|c|}{ Crisis plans } \\
\hline & & \multicolumn{2}{|c|}{ Legislative process } & & $\mathrm{x}$ \\
\hline & $\mathrm{x}$ & $\mathrm{x}$ & $\mathrm{x}$ & $\mathrm{x}$ & $\begin{array}{l}\text { Rescue } \\
\text { operations }\end{array}$ \\
\hline
\end{tabular}

Source: Author.

*x means no cooperation.

Table 7: Cooperation between the basic components of the IRS and NGOs according to level of cooperation.

\begin{tabular}{llll}
\hline Level of cooperation & Czech Republic level & Regional level & Municipal level \\
\hline Type of cooperation & Financial support & \\
& Sharing information & \\
& Task force sessions & \\
& Crisis plans \\
& Rescue operations \\
\hline
\end{tabular}

Source: Author.

Some emergencies have a local character, others affect a larger share of the country, so the rescue and recovery operations could require coordination at any or all levels. Therefore, it is necessary to share information across levels, not only during an emergency, but also between emergencies. Task forces and the crisis plans are present at all levels of government, in some places with the involvement of NGOs. Financial support goes to NGOs from the municipal authorities, regional authorities, and the national institutions such as ministries. It is, therefore, necessary that the IRS (including the participating NGOs) be ready for all possibilities, and for the cooperation at various levels.

To summarize the main findings of this section, it is apparent that the cooperation among NGOs and the state is both formal and informal. The fact that the NGOs became integrated into the IRS, has been beneficial in clarifying emergency management and its processes. At 
the same time, the prevailing independence of NGOs can be seen as an additional tool in emergency management, which can cover the gaps in state participation.

NGOs and the state increasingly cooperate in 'peace time' and not only in emergencies, with the benefit of improving mutual trust, which can improve cooperation and coordination during an emergency. NGOs cooperate with the state at various levels: European, national, regional, and municipal. This is seen as essential and strength of the Czech model. Through discussions, groups like 'Panel' work together after each flood on the weak areas of NGO participation and coordination and try to find solutions. Coordination was insufficient in the past, and there have been efforts to improve that. The key representatives of the NGOs are in contact, trying to institutionalize their cooperation. There is competition (for donors, volunteers, and support from the public and from local authorities), but the NGOs at least partly understand that the most important part of their emergency activities is to minimize the impact of emergency.

Cooperation among NGOs and the state varies in many ways: in formality, timing, level, and type. The cooperation could take the form of financial support. NGOs also have the opportunity to influence legislation and become an official part of the IRS. According to the all NGO representatives, the most important factor influencing cooperation is the sharing of information [3]. Insufficient cooperation can diminish the effectiveness of participation in emergency management. But improved cooperation and coordination can increase the effectiveness.

\section{CONCLUSION}

The Czech Republic has a significant non-profit sector involved in emergencies. This includes non-qualified volunteer activities, such as cleaning up debris, and specialized volunteers, including firefighters and rescuers. NGOs also arrange public fundraising in emergencies like floods, so significant additional financial resources flow through them.

Not all cooperation between government and NGOs is formalized; it can be formal or informal. Cooperation during 'peacetime' is very important for effective cooperation during emergencies. Peacetime cooperation allows the establishment of contacts and mutual trust among NGOs and other emergency actors.

There are several major types of cooperation for NGOs, notably sharing information, receiving financial support, receiving approvals or accreditations and signing contracts, and cooperating in the legislative process. Sharing information is one of the pillars for effective cooperation at recovery operations, not only during emergencies, but also in peacetime. Information sharing has become quite evolved. NGO representatives regularly meeting their colleagues from government and other NGOs; such meetings improve cooperation.

NGOs exist in a particular legal environment: they have to follow the rules, and some activities, such as providing public collections, require approval. It is possible to receive accreditation for volunteer programmes, including emergency volunteer programmes. This certification is not compulsory, but an NGO can receive financial support for it, and for contractual agreements with the FRS. This raises the question of how independent and NGOs are in that case, but these contracts and agreements present many other advantages, such as better participation in the system and more finances for their activities.

NGOs have various contributions in emergencies: volunteers, material aid, and finances. Their financial needs could explain many types of cooperation. Certainly, the cooperation with European Commission through the European Structural Funds has financial reasons; 
such reasons are also a factor in meeting the need of the accreditation committee or contracts with the government. NGOs operate in emergency management with lower expenses than the state as a result of the high use of volunteers. There is no current evidence that NGOs or volunteers would perform emergency management activities at a significantly lower standard than necessary. Thus their activities are cost-effective in comparison to the state. NGOs are not able to do everything in emergency management, although volunteers could be used for part of the IRS.

NGOs have the opportunity to comment on laws and crisis plans. There is no available analysis of the success of their efforts, but they are at least invited to that process. The Czech Republic's experience could be interesting for other countries, especially for the countries from the Central and Eastern Europe, emerging from Communist regimes with little experience of NGO cooperation.

The purpose of the research was to identify the current forms of cooperation between government and non-governmental organizations.

The most important parts of the Czech model are:

1. NGOs and volunteers are part of the national system of emergency management (the participation of NGOs and volunteers is officially possible by law and this possibility is being used, both by NGOs and volunteers). The value of the emergency volunteers is significant (e.g. more than 800, 000 EUR in the Czech flood in 2013).

2. The state (basic components of the IRS and local authorities) views NGOs as partners.

3. The state relies on NGOs in emergency planning (crisis plans).

4. The state is willing to share necessary information with NGOs about the needs of the citizens and areas when emergencies occur.

5. NGOs are willing to cooperate and share information with each other and with the state.

6. The emerging trust and willingness to cooperate (from the NGOs and from the state) has not been ruined by a huge scandal (failure) that could hinder relationship building.

7. NGOs cooperate (with the state and with each other) during emergencies and between emergencies.

8. There is a visible tendency to evaluate the most recent big emergency in a broader forum (professionals from the state authorities, Fire Rescues Service, NGOs, etc.) and to find solutions for any problems that occurred.

9. The human capacity of the state forces is lower than the needs of the public if there is a big emergency such as a flood (because the Czech army is not large enough, etc.).

10. There are many available volunteers and donors for emergencies, enabling the participation of the NGOs in emergency management.

No summary information about the models in other post-communistic countries were found. Future research in other countries and the subsequent comparison with the Czech model could be fruitful. These countries have a similar history, and they are geographically close, so one flood very often affects more than one country. As NGOs and states authorities sometimes need to cooperate with the NGOs and authorities from other countries, it could be beneficial to have complex information available on how the systems work in the neighbouring countries. In a deeper exploration of a country's specifics, the ten parts of the Czech model could be a useful benchmark in understanding the situation in a particular country and determining how it can be improved. 


\section{REFERENCES}

[1] Carson, E.D., Public expectations and nonprofit sector realities: a growing divide with disastrous consequences. Nonprofit and Voluntary Sector Quarterly, 31(3), pp. 429436, 2002. doi: http://dx.doi.org/10.1177/0899764002313007

[2] Wetmore, J.M., Distributed risks and responsibilities: flood hazard mitigation in New Orleans. Social Studies of Science, 37(1), pp. 119-126, 2007. doi: http://dx.doi. org/10.1177/0306312706069433

[3] Rektořík, J., Šelešovský, J., Bakoš, E., Dostál, J., Furová, L., Šrámková, T. \& Smutný, M., Zpráva z výzkumného projektu "Ekonomické a finanční dopady živelních pohrom”. Masaryková univerzita: Brno, 2011.

[4] Stys, J.J, Non-Profit Involvement in Disaster Response and Recovery, Prepared for the Center for Law, Environment, Adaptation and Resources (CLEAR), University of North Carolina School of Law, 2011. Available from: http://www.law.unc.edu/documents/ clear/nonprofit.pdf

[5] Eller, W.S. \& Gerber, B.J., Voluntary nonprofit organizations and disaster recovery: assessing the value of the nonprofit contribution to the 2009 Alaskan rivers flood recovery effort. Unpublished Report, National Voluntary Organizations Active in Disaster, 2010.

[6] Brudney, J.L. \& Gazley, B., Planning to be prepared: an empirical examination of the role of voluntary organizations in county government emergency planning. Public Performance \& Management Review, 32(3), pp. 372-399, 2009. doi: http://dx.doi. org/10.2753/pmr1530-9576320302

[7] McGuire, M., Collaborative public management: assessing what we know and how we know it. Public Administration Review, 66, pp. 33-43. 2006. doi: http://dx.doi. org/10.1111/j.1540-6210.2006.00664.x

[8] Gazley, B., Nonprofits and COADs in disaster planning: are we building collaborative capacity? Paper presented at the University of Central Florida Conference, Building Disaster Resiliency and Sustainability, 381-391 2012.

[9] Bennett, J., Duffield, M., Juma, M.K., Borton, J., Burge, A., \& Benson, C. Meeting Needs: NGO Coordination in Practice. Earthscan Publications Ltd: London, 1995.

[10] Diagne, K., Governance and natural disasters: addressing flooding in Saint Louis, Senegal. Environment and Urbanization, 19(2), pp. 552-562, 2007. doi: http://dx.doi. org/10.1177/0956247807082836

[11] McLennan, J. \& Birch, A., A potential crisis in wildfire emergency response capability? Australia's volunteer firefighters. Environmental Hazards, 6, pp. 101-107, 2005. doi: http://dx.doi.org/10.1016/j.hazards.2005.10.003

[12] Thompson, A.M. \& Bono, B.A., Work without wages; the motivation for volunteer firefighters. American Journal of Economics and Sociology, 52, pp. 323-343, 1993. doi: http://dx.doi.org/10.1111/j.1536-7150.1993.tb02553.x

[13] Yarnal, C.M. \& Dowler, L., Who is answering the call? Volunteer fire-fighting as serious leisure. Leisure/Loisir, 27(3-4), pp. 161-189, 2002. doi: http://dx.doi.org/10.1080/149 $\underline{27713.2002 .9651302}$

[14] International Federation of Red Cross and Red Crescent Societies. The Value of Volunteers: Imagine How Many Needs Would Go Unanswered Without Volunteers. International Federation of Red Cross and Red Crescent Societies: Geneva, 2011. 
Available from: http://www.ifrc.org/Global/Publications/volunteers/IFRC-Value\%20 of\%20Volunteers\%20Report-EN-LR.pdf

[15] Dostál, J., Cooperation between non-governmental organizations and the State in the matter of flood risk management in the Czech Republic. Flood Recovery, Innovation and Response III, eds. D. Proverbs, S. Mambretti, C.A. Brebbia, \& D. De Wrachien, WIT Press: Southampton, UK, pp. 15-26, 2012. doi: http://dx.doi.org/10.2495/friar120021

[16] Kavan, Š., Ochrana Obyvatelstva I, Vysoká škola evropských a regionálních studií: České Budějovice, p. 109, 2011.

[17] Kumar, P., NGO Coordination in Humanitarian Action: The Case of the Czech Floods of August 2002, Massachusetts Institute of Technology: Cambridge, MA, 2005.

[18] Dostál, J. \& Balarinová, L., Volunteers in emergency management - an investment in the future? WIT Transactions on the Built Environment, 133, pp. 381-391, 2013. doi: http://dx.doi.org/10.2495/dman130341

[19] Paul, B.K., Relief assistance to 1998 flood victims: a comparison of performance between the government and NGOs. The Geographical Journal, 169, 2003. doi: http:// dx.doi.org/10.1111/1475-4959.04958

[20] Pospísil, M., History of the Czech Nonprofit Sector, 2006. Available from: http://www.ecvns.cz/soubory/History_CZ_update09.pdf.

[21] Vurst, V., Úvodní prezentace na konferenci Limity a rizika dobrovolnické pomoci při mimořádných událostech a krizových situacích, Ministry of Interior of the Czech Republic: Prague, 2010.

[22] Kavan, Š., Dostál, J., Mezníková, M., Müllerová, V., Neškodná, J. Dobrovolnictví a nestátní neziskové organizace při mimořádných událostech v podmínkách Jihočeského kraje, Vysoká škola evropských a regionálních studií: České Budějovice, p. 69, 2012.

[23] Prudil, L., Úvodní slovo na konferenci Příležitosti dobrovolnictví při mimořádných událostech a krizových situacích, Ministry of Interior of the Czech Republic: Prague, 2013.

[24] Annual Report of the Fire Rescue Service, Prague, 2002. Available from: http://www. hzscr.cz/soubor/rocenka-2002-pdf.aspx.

[25] Annual Report of the Fire Rescue Service, Prague, 2013. Available from: http://www. hzscr.cz/soubor/rocenka-2013-pdf.aspx.

[26] Kavan, Š., Jednotky dobrovolných hasičů a sdružení dobrovolných hasičů při povodních, Dobrovolnictví a nestátní neziskové organizace při řešení následků povodní v ČR. Sborník z workshopu a semináře Protipovodñového vzdělávacího a výzkumného centra, J. Dostál, J. Soukopová, Brno: Masarykova Univerzita, 2014. pp. 45-57. ISBN 978-80210-6713-4.

[27] Horská služba je po náročném roce připravena na zimu. Horská služba ČR [online], Prague, 2011, 7.12.2011 [cited 2013-02-04]. Available from: http://www.hscr.cz/index. php?option $=$ com_content $\&$ task $=$ view $\&$ id $=1562 \&$ Itemid $=139$

[28] Palubinskas, G.T., Democratization: the development of nongovernmental organizations (NGOs) in Central and Eastern Europe. Public Administration and Management, 8(3), 150-163, 2003. doi: http://www.spaef.com/file.php?id=271

[29] Law no. 239/2000 on Integrated Rescue System.

[30] Ministry of Interior of the Czech Republic. In Case of Danger - Citizens' Handbook [cited 2013-02-04]. Available from: http://www.mvcr.cz/mvcren/article/in-case-ofdanger-citizens-handbook-590735.aspx. 
[31] International Labour Organization, Manual on the Measurement of Volunteer Work, International Labour Office: Geneva, March 2011.

[32] Salamon, M.L., Sokolowski, W. \& Haddock, M.A., Measuring the economic value of volunteer work globally: concepts, estimates, and a roadmap to the future. Annals of Public and Cooperative Economics, 82(3), pp. 217-252. ISSN: 1467-8292. 2011.a

[33] The Ministry of Labour and Social Affairs of the Czech Republic. The Information System on the Average Earnings, 2013. Available from: http://www.ispv.cz/cz/ Vysledky-setreni/Archiv/2013.aspx

[34] Ministry of the Interior of the Czech Republic. Voluntary service. [cited 2013-02-04]. Available from: http://www.mvcr.cz/clanek/dobrovolnicka-sluzba-500539.aspx?q=Y2hudW09Mw\%3D\%3D

[35] Government Council is the Council for Non-Governmental /Non-Profit Organisations. Basic information. Available from: http://www.vlada.cz/cz/ppov/rnno/zakladniinformace-767/

[36] Government Council is the Council for Non-Governmental /Non-Profit Organisations. Members of the council. Available from: http://www.vlada.cz/cz/ppov/rnno/clenove/ default.htm

[37] Bucharová, E., Zkušenosti z povodní: Diakonie ČČE, Příležitosti dobrovolnictví při mimořádných událostech a krizových situacích, Ministry of Interior of the Czech Republic: Prague, 2013. 